\title{
Theoretical and practical aspects of social responsibility of food market participants
}

\author{
Nikolay Belyaev*, Lyudmila Donskova, and Olga Zueva \\ Ural State University of Economics, 8 March /Narodnaya VolyaStr., 62/45, 620144 Ekaterinburg, \\ Russia
}

\begin{abstract}
The authors consider theoretical and practical aspects of the formation and application of the principles of social responsibility of the main food marketparticipants: producers, retail and consumers to optimize the directions of its development. It is established that the main provisions Of the manual on social responsibility, an international reference document on social responsibility, form the essential theoretical basis for the development of this direction at the present time. Considering the practical aspects of applying social responsibility in the food industry and food retail, the authors highlight the topic of responsibility to consumers as a priority. Sincethese participants of the trophological chain are responsible for making decisions regarding the level of quality, authenticity, naturalness and safety of products within the requirements of regulatory documents and consumers. The article defines the principles of social responsibility of the consumer as afood market participant. The authors believe that the research results can serve to build a holistic theory of market development in the new economy, which is characterized by high quality processes and can be useful for the business community as an idea of possible investments.
\end{abstract}

\section{Introduction}

The emergence of a fundamentally new phenomenon in public life in a market economy "social responsibility" has attracted the attention of many scientists and practitioners, whose research has resulted in the recognition of the importance and necessity of social responsibility at the level of the world community in such areas as environmental protection, protection of natural resources, energy and resource conservation, and others [1]. At the same time, Le Ha Nhu T. \& Velencei J. [2] emphasize thatin the modern world there are many problems related to corporate social responsibility (CSR) in relation to sustainable development: from global issue of the relationship between corporate social responsibility and firm performance before the application of CSR principles in small and medium business in various sectors of the economy [2, 3, 4]. The study of the application of the provisions of social responsibility in the sphere of production and circulation of food is also relevant. It is the food market, which represents a system of socio-economic relations in the field of food production, transportation, storage and sale, that is one of the most

\footnotetext{
* Corresponding author: nikolaybb1@mail.ru
} 
significant, affecting the quality of life of any economic entity. Achieving its balanced development is one of the main goals of the global, national and regional economies. The analysis of the few literature data shows that the topic has a general theoretical, and a debatable nature in applied issues, and requires study and analysis based on a systematic and integrated approach, which determined the choice of research direction.

Therefore, the purpose of this research, the main provisions of which are reflected in the article is to study theoretical and practical aspects of formation and application of principles of social responsibility core subjects of the food market: manufacturers, retailers and consumers to optimize the directions of its development.

\section{Methods}

In order to achieve this goal, bibliographic, system, logical, analysis and synthesis methods were used as theoretical ones, while methods of publication research and expert evaluations were used as applied ones.

\section{Results and Discussion}

Theoretical approaches to social responsibility. Different definitions of social responsibility have been proposed in different years. According to most experts, the most accurate and complete definition is the international standard ISO 26000 "guide to social responsibility", which was approved by more than 500 experts. Social responsibility, in accordance with ISO 26000, is the responsibility of an organization for the impact of its decisions and activities on society and the environment through transparent and ethical behavior that: promotes sustainable development, including the health and well-being of society; meets the expectations of stakeholders; complies with applicable legislation and international standards of conduct; and is implemented throughout the organization. According to the authors, the main provisions of this international reference document on social responsibility form the essential theoretical basis for the development of this direction at the present time

The guide contains seven 7 coresubjects., which are shown in figure 1.

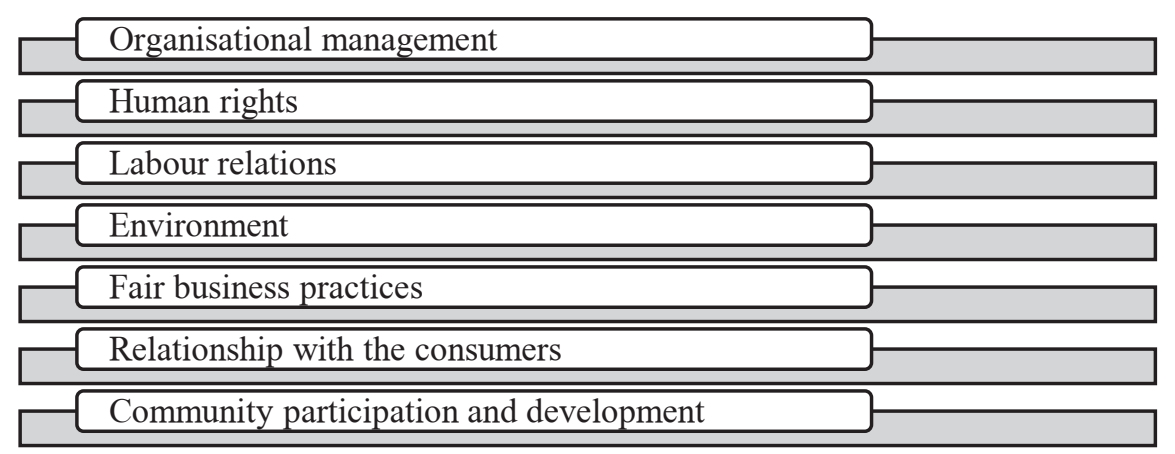

Fig. 1. Social responsibility: 7 coresubjects

Agreeing with the opinion of individual experts, we believe that each company chooses its own key areas of responsibility within its sphere of activity [3].

Practical aspects of social responsibility offood market participants. 
Social responsibility of producers of raw materials and food products asfood market participant, is a special topic. Social orientation of the food market is a modern trend in the development of the global food system, which encourages producers to innovate in the field of technology and sales of goods, and requires to be safe for the consumer and contribute to strengthening national security.

Food production is closely linked to one of the global problems of humanity - the food problem. It is the food industry, representing the most important socially significant sector of industry in any country or state, including Russia, consisting of several dozen sub-sectors united by the unity of the purpose of the products produced, that is designed to provide the population with safe food in the required quantity and appropriate quality.

However, at present, manufacturers, pursuing the goal of creating a commercial product that would provide businesses with high and stable profits by reducing costs, push aside issues related to quality and safety. In this aspect, the features of the functioning of meat industry enterprises were previously considered [5]. Using the accumulated experience, the results of the $\mathrm{FAO} / \mathrm{WHO}[6]$, in which 22 countries participated, the authors give as an example some characteristics that are necessary for determining and strengthening the role of social responsibility in the food industry.

1. Rapid development of modern food technologies, including nanotechnologies, production of genetically modified products, etc.

2. The use of a wide range of food additives, many of which are products of chemical synthesis and are foreign to the human body. Already, according to FAO/WHO, about $3 \mathrm{~kg}$ of additives from different technological groups enter the human body.

3. Falsification of food products, which has acquired an international character, as evidenced by $55 \%$ of the countries participating in the survey [6].

4. Information asymmetry is characteristic of the food market, aimed at forming an image of falsified well-being in relation to product safety, authenticity and naturalness [7, 8]. According to a study by Grunert \& Aachemann [7], which provides reviews from 35 published studies on how EU quality marks affect consumers, The authors agree with the researchers' opinion that quality marks, for example, reflected in labeling, can only have a function to the extent that consumers know about them, understand them, and use them in decision-making.

5. The presence of advertising, often aggressive in nature, persistently and inventively contributes to the inventive manipulation of consumer behavior and choice.

6. The world community has begun to pay more attention to the issues of food loss and spoilage, considering food losses that occur in the food supply chain from harvest/slaughter/catch up to entering the retail system (without taking into account the last stage), and food spoilage as a phenomenon that occurs at the stages of retail trade and consumption. According to $\mathrm{FAO} / \mathrm{WHO}, 30 \%$ of food produced for human consumption is globally lost or wasted somewhere along the food supply chain, amounting to approximately 1.3 billion tons per year $[9,10]$. Food loss and spoilage can have an impact on food security and nutrition, resulting in changes in four dimensions: availability, access, use, and stability. Meanwhile, The world's population is projected to reach 9.1 billion by 2050 , and this will require a $70 \%$ increase in food availability. The problem requires a transition from the traditional approach to assessing the causes of food losses at each stage of the supply chain to an integrated approach [10].

The global role of the food industry in the sustainable development of our world, in its well - being and wellfare is recognized by the world community, that is why the ISO technical Committee ISO / TC 34, Food products has developed ISO / TS 26030-an application for the food sector of the ISO 26000 standard, the guide to social responsibility, the flagship ISO standard on social responsibility for food companies, farms, cooperatives, processors and retailers, regardless of their size or location. This document provides 
guidance on the use of the ISO 26000 standard in the food chain, focusing on the main aspects of its seven core subjects. ISO / TS 26030, Social responsibility and sustainable development -provides guidelines on how an organization in the food production chain can contribute to sustainable development, taking into account all local laws, regulations and stakeholder expectations.

A special feature of this research is the consideration of the specifics of social responsibility of another food market participant- modern food retail, which is a retail trade in food products.

The participation of retail trade organizations (primarily network structures) in the implementation of the principles of corporate responsibility is evidenced by the facts reflected in various publications on the development of retail trade. At the same time, for both domestic and foreign retail chains, there is a close connection between business and social investment. It is retail trade enterprises that ensure food well - being and take part in charity events, actions to protect the environment, improve the territory in the locations of stores, provide assistance to socially vulnerable people, etc. [11-13].

However, the most significant component of corporate social responsibility of retail trade organizations from the point of view of customers is the high quality and safety of goods sold and the quality of services provided. Research by Russian scientists [13] found that among the CSR components of retail trade organizations, the most significant, in the opinion of buyers, are the sale of quality goods, it was noted by $87.6 \%$ of respondents, the least important - only $1.6 \%$, as well as quality customer service $(63 \%$ and $3.1 \%$, respectively).

Thus, the manufacturer and retail are responsible for meeting the requirements for the quality and safety of manufactured and sold goods [9], as a result of which, according to the authors, the priority is the topic related to responsibility to consumers. In summary, the problems associated with consumers in the context of the document "guide to social responsibility" are presented in figure 2 .

\begin{tabular}{|l|l|}
\hline 1 & $\begin{array}{l}\text { - Good practices in marketing, Contracting, and providing unbiased } \\
\text { information based on facts } \\
\text { - health protecton and safety of consumers }\end{array}$ \\
\hline $\mathbf{2}$ & $\begin{array}{l}\text { - Sustainable consumption } \\
\text { - Customer service and support and resolution of claims and } \\
\text { complaints }\end{array}$ \\
\hline $\begin{array}{l}\text { - Education and awareness } \\
\text { - Access to essential services } \\
\text { - Protecting consumer data and privacy }\end{array}$ \\
\hline
\end{tabular}

Fig. 2. Problems related to consumers

The world organization of Consumers (Consumers International) calls for paying attention to the problems of excessive production and irrational consumption, which leads to global climate change, environmental degradation, and the loss of unique natural objects.

In this regard, the role and place of social responsibility in the behavior of consumers is of interest from a scientific and practical point of view to study, as another food market participant. The call for socially responsible consumer behavior is particularly relevant due 
to the aggravation of social problems and environmental pollution, and becomes mandatory in the context of the evolution of the entire society [13].

\section{Conclusions}

1. The issues of participation of business structures in the life of society, ensuring a fair distribution of material benefits and solving social problems of the General population are becoming particularly relevant in the new economy, one of the features of which is qualitative processes.

2. Research on corporate social responsibility in the food sector is recognized by the authors as a relevant area, since the food market is one of the most significant, as it is associated with the life and livelihood of the population.

3. The theoretical and methodological basis of corporate social responsibility is formed by the works of foreign and domestic scientists, as well as international reference documents on social responsibility: ISO 26000 "guide to social responsibility" and ISO / TS 26030 "Social responsibility and sustainable development".

4. Considering the state of the food industry, it is established that there are features that characterize the current state of the industry: critical problems include falsification and forgery of food, problems related to new technologies, alimentary pathogens problems related to food additives and problems related to food safety (alimentary pathogens, foreign impurities, mycotoxins, etc.). It is established that among the components of CSR of retail trade organizations, the most significant, in the opinion of buyers, are the sale of quality goods, as well as quality customer service.

5. Given that it is the manufacturer and retail that make decisions about the level of compliance with the requirements for the quality and safety of food products, thereby determining the level of risk as a result of its consumption, the authors identified as a priority the topic related to the responsibility of business to consumers. And only after the implementation of this direction the company can develop measures aimed at implementing social investments.

6. As a result of the research, the problems and mechanism of implementing social responsibility for business related to consumer responsibility were clarified and corrected, which includes, first of all, the production and provision of high-quality and safe goods that determine their functionality, authenticity and naturalness; conducting an assessment of human health risks in the production of new products, the introduction of new materials and technologies; applying good marketing practices and providing truthful information about products and their properties in a form that is understandable to consumers; availability of procedures for compensation of damages in case of provision of goods of unsatisfactory quality; etc.

7. The principles of consumer social responsibility are defined, which include: utility and prevention, awareness, thrift and efficiency, quality and safety of food products, consumer culture, refusal from excessive and irrational consumption.

\section{Acknowledgements}

The authors express their gratitude to the translator and editor for their professional approach to the work, as well as to their colleagues for their support in the process of working on the manuscript. 


\section{References}

1. N.N. Ignatenko, Baltic Humanitarian Journal, 1 (10) (2015)

2. T. Le Ha Nhu, J. Velencei, In Proceedings of the 16th International Conference of Management, Enterprise and Benchmarking (2018)

3. B. Bataeva, Organizational Psychology, 8, (2018)

4. Z.R. Reicher, Economic and Management Spectrum, 13(1) (2019)

5. L.A. Donskova, Manager, 2 (32) (2013)

6. Critical Factors for Food Safety and Quality in the Russian Federation, https://www.codexalimentarius.nl/

7. Riivits-Arkonsuo, A. Leppiman, J. Hartšenko, Agronomy Research,14(3) (2016)

8. M.V. Sheina, Perm University Herald. Economy, 3 (26) (2015)

9. FAO. Global Initiative on Food Loss and Waste Reduction, http://www.fao.org/ (2015)

10. Maryam Rezaei, Bin Liu, Nut fruit, 71 (2017)

11. I.V. Degtyareva, G.F. Tokareva, O.I. Shalina, Bulletin of PNRPU, Socio-economic sciences, 3 (2016)

12. A.S. Yurina, Colloquium-journal, 2 (26) (2019)

13. G.G. Ivanov, E.A. Mayorova, Russian Entrepreneurship, 16 (20) (2015) 